\title{
Konsep Sabilillah dalam Pandangan Syekh Mahmud Syaltut dan Implementasinya dalam Hukum Islam Kotemporer
}

\author{
Ahmad Zulfikar \\ Institut Perguruan Tinggi Ilmu Al Qur'an, Jakarta \\ Email: fikar.books@gmail.com
}

\begin{tabular}{|c|c|}
\hline Keywords: & Abstract: \\
\hline $\begin{array}{l}\text { Sabilillah, Syaltut, } \\
\text { jihad }\end{array}$ & $\begin{array}{l}\text { This paper reviews the meaning of the phrase sabilillah in the view of Shaykh al- } \\
\text { Azhar, Al-Imam Al-Akbar, Shaykh Mahmud Syaltut. Discussing this phrase, Syaltut } \\
\text { uses the maudhu'i interpretation method which is implemented in many of his works. } \\
\text { By using the library research method, data related to Syaltut thought is collected and } \\
\text { analyzed. From these data, the concept of sabilillah in view of Syaltut includes } \\
\text { universal values of life established by Islamic law: goodness, justice, cooperation } \\
\text { and compassion; and sabilillah is how to realize the objectives of Islamic law itself. } \\
\text { With this understanding, Islamic law in the hands of Syaltut appears dynamic in } \\
\text { accordance with the context of his era. }\end{array}$ \\
\hline Kata kunci: & Abstrak: \\
\hline $\begin{array}{l}\text { Sabilillah, Syaltut, } \\
\text { jihad }\end{array}$ & $\begin{array}{l}\text { Artikel ini mengulas tentang pemaknaan frasa sabilillah dalam pandangan Syaikhul } \\
\text { Azhar, Al-Imam Al-Akbar, Syekh Mahmud Syaltut. Membahas frasa ini, Syaltut } \\
\text { menggunakan metode tafsir maudhu'i yang dimplemen-tasikan dalam banyak } \\
\text { karyanya. Dengan menggunakan metode dlibrary research, data-data yang berkaitan } \\
\text { pemikiran Syaltut dikumpulkan dan dianalisis. Dari data-data itu, konsep sabilillah } \\
\text { dalam pendangan Syaltut mencakup nilai-nilai universal kehidupan yang ditetapkan } \\
\text { hukum Islam: kebaikan, keadilan, kerja sama dan kasih sayang; dan sabilillah adalah } \\
\text { bagiamana merealisasikan tujuan syariat Islam itu sendiri. Dalam realisasi konteks } \\
\text { sekarang ini sabilillah tersebut dapat diartikan dalam zakat yang manfaatnya lebih } \\
\text { dirasakan secara langsung oleh masyarakat. Dengan pemahaman demikian, hukum } \\
\text { Islam ditangan Syaltut tampil dinamis sesuai dengan konteks zamannya. }\end{array}$ \\
\hline
\end{tabular}

Received: March 4, 2020. Revised: April 24, 2020. Accepted: April 26, 2020

\section{Pendahuluan}

Makna bukan lain adalah sesuatu atau referen yang diacu oleh kata. Akan tetapi, yang perlu dipahami adalah tidak semua kata mempunyai acuan konkrit di dunia nyata. Lain dari itu, dalam penggunaan penuturan, makna kata sering kali keluar dari makna konsep dasarnya (Abdul Chaer 2012: 288). Dalam istilah ushul fikih makna yang menjadi konsep dasar dari suatu kata disebut dengan makna wadh' $i$, sedangkan makna yang sudah lepas dari makna konsep dasar disebut dengan majas (Liguistik Umum: 88).

Menurut Abdul Chaer (2012: 88), suatu kata atau frasa baru dapat diketahui maknanya apabila ia sudah berada dalam konteks kalimat. Dalam kelanjutannya, makna kalimat itu sendiri baru dapat ditentukan apabila kalimat itu berada dalam konteks wacananya atau konteks situasinya (Liguistik Umum: 88). Upaya seperti inilah yang dilakukan oleh Syekh Mahmud Syaltut untuk mengetengahkan makna sabilillah dalam berbagai konteks dan situasi penggunaannya. Akan tetapi, hal itu disampaikan 
hanya sekilas, padahal frasa sabilillah perlu mendapatkan perhatian khusus agar apa yang dikhawatirkan oleh Syekh Mahmud Syaltut tidak terulang lagi di zaman sekarang.

Diakui frasa sabilillah sering dipahami keliru oleh banyak kalangan. Jika diurai, frasa tersebut terdiri dari kata sabil dan Allah; sabil berarti jalan. Ahmad bin Faris (1979:130) menyebutkan, sabil dimaknai jalan karena jalan adalah bentangan yang menjulur panjang. Kata ini berasal dari tiga huruf, sa-ba-la yang berarti jatuh dari atas ke bawah atau menjulur dari atas ke bawah. Lalu, kata tersebut disandarkan kepada Allah sebagai susunan idhafah (frasa), maka sabilillah berarti jalan Allah. Kata ini banyak muncul dalam ayat-ayat Al-Qur'an. Seringnya, ia muncul dalam tema jihad sehingga muncul pemahaman bahwa jihad, dalam arti perang, dinyatakan sebagai perang suci di jalan Allah.

Mengingat bahwa perang suci ini balasannya adalah surga, maka ayat-ayat yang berkaitan dengan jihad diserukan dalam rangka memobilisasi massa untuk melakukan jihad. Akan tetapi, oleh sebagian orang frasa sabilillah ini dianggap sebagai kewajiban mutlak berperang tanpa memperhatikan konteks di mana frasa sabilillah itu digunakan.

Satu di antara ulama besar yang menyinggung pembahsan frasa ini adalah Syekh Mahmud Syaltut. Dalam bukunya, Al-Qur'an wa Al-Qital (1951:35), beliau prihatin terhadap sebagian pemahaman ulama di zamannya tentang makna sabilillah dalam banyak ayat Al-Qur'an. Dalam bukunya itu, surah At-Taubah ayat 5, Qatilulladzina yalunakum minal kuffar (Perangilah orang-orang kafir yang di sekitar kamu itu) dipahami sebagian ulama di masanya, bahwa Islam memerintahkan para pemeluknya membunuh semua orang kafir, tanpa membedakan apakah mereka terlibat permusuhan dengan kaum Muslimin ataupun tidak. Yang penting orang-orang kafir itu harus memeluk Islam. Jika tidak masuk Islam, mereka harus diperangi. Mereka mengklaim, inilah syariat Islam. Padahal, ayat itu menunjuk kepada musyrik Arab yang memerangi kaum Muslimin, merampas harta mereka, bahkan mengusir mereka dari Mekkah.

Demikian pula, hadits Nabi Saw., Umirtu an uqatilan nas (Aku diperintahkan memerangi orang-orang) (Al-Quraisyi 2003:53) yang dipahami oleh mereka sebagai perintah memerangi nonMuslim. Padahal, menurut Syaltut (1951:35), konteks hadits tersebut dinyatakan untuk orang-orang musyrik Arab yang pada waktu itu kaum Muslimin dimusuhi dan diusir dari tanah kelahiran mereka.

Tentu, jika pemahaman ini dibiarkan akan tercipta suasana konflik yang berkepanjangan, baik dilihat dari sisi dalam negeri maupun luar negeri. Maka, melalui metode tafsir maudhu'i (tematik), Syekh Mahmud Syaltut menyampaikan gagasannya terkait pemaknaan frasa sabilillah itu. Hanya saja, gagasan itu tersebar dalam karya-karyanya. Maka dari itu, tulisan ini akan mengungkap makna frasa sabilillah secara tematis-komprehensif sesuai dengan metode tafsir maudhu'i. Kemudian, dari hasil penafsiran secara tematis itu akan diimplementasikan dalam fikih kontemporer.

Karena dalam kandungan Al-Qur'an dan relasi umat Beragama memiliki prinsip dasar yang harus kita pegang serta kita kembangkan. Berangkat dari perbedaan penafsiran Al-Qur'an terkait bagaimana Al-Qur'an menyikapi relasi umat beragaman bahwa dalam sejarah relasi umat beragama, Al-Qur'an mengedapankan nilai-nilai universal: keadilan, kesetaraan, persaudaraan dan dialog antar manusia. Nilai-nilai iniah yang seharusnya dipupuk dan dikembangkan dalam rangka membina relasi umat beragama yang lebih harmonis. (A. Zulfikar dan M. Afwan Romdloni, 2019: 1). Sehingga konsep sabilillah yang lebih aplikatif dan lebih besar manfaatnya harus kita kembangkan demi kesejahteraan umat manusia secara umum.

\section{Metode Penelitian}

Seperti yang telah disebut, penulisan ini akan menggunakan pendekatan tafsir maudhu'i yang dikemukakan oleh Syaltut terkait frasa sabilillah. Tafsir maudhu'i (tematik) adalah corak tafsir yang membahas tentang masalah-masalah Al-Qur'an dalam kesatuan makna, tema dan tujuan dengan cara menghimpun ayat-ayat yang berkaitan dengan makna, tema dan tujuan yang dimaksud. Kemudian, 
dilakukanlah penalaran (analisis) terhadap isi kandungan ayat-ayat tadi menurut cara-cara tertentu dan berdasarkan syarat-syarat tertentu untuk menjelaskan makna-maknanya dan mengeluarkan unsurunsurnya serta menghubungkan-hubungkan antara yang satu dengan yang lain dengan korelasi yang bersifat komprehensif (Ahmad Izzan 2014:114).

Berdasarkan pendekatan itu, maka penulis akan menggunakan jenis penelitian kepustakaan (library research). Penelitian kepustakaan khususnya dalam bidang tafsir, seperti yang dinyatakan oleh Nashruddin Baidan (2016:27), adalah penelitian yang semua datanya berasal dari bahan-bahan tertulis: buku, naskah, dokumen, foto dan lain sebagainya. Akan tetapi, semuanya harus berkenaan dengan tafsir. Maka dari itu, dalam penelitian ini subjek penelitiannya adalah frasa "sablillah", sementara objek penelitiannya adalah pemaknaan Syaltut terhadap frasa tersebut. Kemudian, data-data tersebut dianalisis dengan induktif dan deduktif.

\section{Hasil dan Pembahasan}

\section{a. Biografi Mahmud Syaltut}

Mahmud Syaltut adalah salah seorang putra Mesir terbaik, lahir pada tanggal 23 April 1893 di desa Minya Bani Mansur, Distrik Itay Al-Barud, Provinsi Buhaira. Ia berasal dari keluarga petani yang taat beragama, ayahnya seorang petani yang memiliki karisma di desanya (Abdul Salam Arief 2003: 201). Sesuai dengan tradisi masyarakat Islam di Mesir pada saat itu, pendidikan Syaltut diawali dengan belajar membaca Al-Qur'an, dan ia berhasil menghafalkannya pada tahun $1906 \mathrm{M}$ saat ia berusia remaja (13 tahun), kemudian ia memasuki lembaga pendidikan agama di al-Ma'had al-Dini di Iskandariyah—sebuah lembaga keagamaan yang berafiliasi dengan Al-Azhar yang baru didirikan.

Mahmud Syaltut juga termasuk sarjana Al-Azhar yang mendukung reformasi ini sehingga gerakan tersebut membuat Raja Faruk risih dan tidak nyaman. Dengan alasan ini pula, Syekh AlMaraghi sebagai penggerak gerbong reformasi dipecat dari jabatannya oleh penguasa pada saat itu, meskipun keilmuan Al-Maraghi tidak dapat disangsikan di kalangan ulama Al-Azhar dan muridmuridnya yang tercerahkan. Akibatnya, Mahmud Syaltut mengalami nasib serupa. Usai pemecatannya ia bekerja sebagai pengacara di Pengadilan Syariah, dan pada Februari 1935 ia dikembalikan pada jabatannya di Al-Azhar bersama dengan tokoh-tokoh reformis lainnya yang sebelumnya telah dipecat (Muhammad Abdul Mun'im 1996: 186).

Pada tahun itu pula, Syaltut menjabat Wakil Dekan Fakultas Syariah, dan pada 1937, ia menghadiri konferensi Internasional di Den Haag mewakili Al-Azhar di antara tiga ulama lainnya. Pidatonya terkait pertanggungjawaban perdata dan pidana dalam hukum Islam mendapat apresiasi sangat tinggi dari semua peserta. Dari pidatonya yang memukau pada konferensi tersebut para pakar hukum sedunia dalam konferensi itu menilai bahwa syariat Islam layak menjadi sumber perundang-undangan modern. Syariah Islam dinilai sebagai tata hukum otentik dan orisinil, bukan hasil diadaptasi dari hukum lain, bukan pula dipengaruhi oleh aliran hukum yang ada. Berkat pidatonya itu pula, bahasa Arab menjadi bahasa Arab sebagai bahasa resmi yang akan dipakai pada konferensi berikutnya. Tidak hanya peserta konferensi, mereka yang berada dalam lingkaran al-Azhar juga ikut terkesan, dan karenanya nama Mahmud Syaltut terangakat dan karirnya melesat di lembaga tersebut. Kemudian pada tahun 1939, Syaltut diangkat sebagai ketua studi agama dan kemudian menjadi anggota Akademi Bahasa Arab di Kairo yang terpilih pada tahun 1946. Karirnya terus meningkat, dan pada bulan November 1957, ia terpilih sebagai wakil rektor.

Setelah puluhan tahun berkiprah baik dalam sekala nasional maupun internasional, setahun kemudian, Syaltut akhirnya diberi kehormatan tertinggi dan diangkat menjadi Syaikhul Al-Azhar oleh Presiden Gamal Abdul Nasser pada Oktober 1958 menggantikan Syekh Abdurraman Taj yang kurang 
disukai oleh Presiden Gamal Abdul Naser. Posisi ini ia duduki sampai meninggal pada 13 Desember 1963.

Tak lama setelah menduduki jabatan sebagai Syaikhul Azhar, Syaltut mengumumkan visinya untuk reformasi (Abdul Mun'im: 186). Syaltut berusaha membuktikan bahwa hukum syariah bukanlan halangan bagi masyarakat modern, tetapi lebih merupakan panduan melalui perubahan yang dibawa oleh masyarakat modern. Dia dengan sungguh-sungguh bertekad untuk membuat Al-Azhar mencapai kemandirian yang lebih besar dari kontrol negara, dan berupaya membuat Majlis Nasional mengeluarkan deklarasi seperti Undang-undang Reformasi, yang mereka lakukan pada tahun 1961. Undang-undang Reformasi bertujuan untuk mengintegrasikan Al-Azhar ke dalam bidang pendidikan tinggi yang lebih luas, meningkatkan kesempatan kerja bagi siswa, dan menghasilkan serjana modern yang berpengetahuan luas dalam dunia kontemporer dan mempu melayani kaum Muslimin.

Syekh Syaltut berusaha untuk menggambarkan Islam ke dunia sebagai agama persatuan, fleksibilitas, dan moderasi. Dia dengan marah mengutuk sektarianisme, pemujaan suci, sambil mempromosikan toleransi dan alasan di kalangan penduduk Islam. Selain itu, Syaltut tidak khawatir menerima sosialisme dan sangat bangga dengan kewarganegaraan Mesirnya sementara pada saat yang sama mendukung Arabisme. Namun demikian, seperti halnya tokoh terkemuka lainnya, Syaltut (dan keseluruhan ulama pada saat itu) ada yang tidak menyukai. Dunia Arab pasca 1960-an pada dasarnya adalah dunia di mana ada krisis kepemimpinan agama. Terlepas dari itu, ia dipandang banyak orang sampai hari ini sebagai seorang reformis hebat yang berusaha memajukan Islam selama masa sulit di dunia Islam (Asyraf Fauzi 1997: 187).

Dalam metode penafsiran Mahmud Syaltut mrmiliki ciri kahs tersendiri sebagaimana dalam bukunya Al-Qur'an wa Al-Qital (1951:5-8), Syekh Mahmud Syaltut merincikan dua metode penafsiran. Beliau menyatakan, ada dua metode penafsiran yang dilakukan oleh para mufasir:

Pertama, Mufasir menafsirkan Al-Qur'an dari ayat atau surah sesuai urutan mushaf. Dimulai dengan menfsirkan kosa-kata, mengaitkan kata dengan beberapa ayat berikut makna-makna kontekstual yang terdapat dalam ayat-ayat lain. Inilah metode yang digunakan sejak tafsir dan para mufasir muncul. Fenomena yang muncul dari metode penafsiran seperti ini adalah masing-masing menafsirkan AlQur'an sesuai dengan kecenderungannya. Mufasir yang cenderung pada kajian balaghah, maka ia akan menerapkan kaidah-kaidah balaghah pada penafsirannya. Sedangkan mufasir yang suka ilmu nahwu akan menafsirkan Al-Qur'an dari sisi gramatikal Arabnya. Berbeda dengan mufasir yang ahli sejarah, maka ia akan menafsirkan berdasarkan ilmu sejarah. Yang ahli filsafat akan menafsirkan dengan filsafatnya sehingga ayat-ayat kisah akan menjadi bagian penting dalam tafsirnya. Sedangkan, para fukaha justru hanya konsen pada sisi hukum sehingga Al-Qur'an semuanya ditafsirkan dari sisi hukum atau fikih. Demikian selanjutnya.

Bagi Syaltut, penafsiran dengan metode tahlili justru akan mempersulit orang-orang yang mempelajari Al-Qur'an dan mencari hidayahnya. Sebab, para mufasir itu dipengaruhi oleh aliranaliran atau pemikiran-pemikiran yang beragam sehingga apa yang mereka tafsirkan justru tidak membuat pembaca tenteram dalam menerima hidayah Al-Qur'an. Jadi, Al-Qur'an yang tujuan utamanya adalah memberi inspirasi dan petunjuk tidak efektif menjalankan misinya. Syaltut memungkasi ulasannya dengan pernyataan yang sangat tajam. Ia menyatakan, demikianlah di tangan mereka Al-Qur'an telah menjadi cabang, padahal seharusnya ia menjadi pokok; Al-Qur'an telah menjadi pengikut, paadahal seharusnya ia harus menjadi yang terdepan; dan Al-Qur'an telah menjadi barang timbangan, padahal seharusnya ia harus menjadi timbangan.

Kedua, mufasir melakukan eksplorasi terhadap semua ayat yang menyinggung satu tema tertentu dan menjadi fokus kajiannya. Setelah terkumpul, ayat-ayat tersebut dianalisis dan dipahami sesuai konteks dan gaya bahasanya. Dari analisis ayat tersebut akan didapatkan kejelasan maksud dari masing-masing ayat dan hubungan antarayat. Dengan demikian, masing-masing ayat ditempatkan pada tempatnya yang sesuai. Kalaupun ada ayat yang maknanya tak sesuai dengan keinginan mufasir 
maka hendaknya makna itu tak perlu disingkirkan, sebab bagaimanapun makna itu, berikut gaya penuturannya, adalah keistimewaan Ilahi yang Maha Bijaksana.

Syekh Mahmud Syaltut, secara tegas menyatakan bahwa metode yang kedua adalah metode yang paling ideal dan itulah metode yang ia terapkan dalam menafsirkan Al-Qur'an. Lanjutnya, jika suatu penafsiran hendak disajikan kepada masyarakat maka metode inilah yang layak digunakan untuk menunjukkan masyarakat pada hidayah Al-Qur'an. Tujuan dari metode ini bukan lain adalah membumikan Al-Qur'an, dalam arti Al-Qur'an bukan hanya berisikan teori, tetapi ia menyentuh pada alam konkret di segala bidang kehidupan.

Berbeda dengan pendahulunya, Syekh Al-Maraghi, Mahmud Syaltut menempuh jalur penafsiran yang berbeda. Jika gurunya menempuh metode tahlili, Syaltut justru menempuh metode maudhu'i. Hal tersebut tampak dalam Tafsir Al-Qur'an Al-Karim Al-Ajza'Al-'Asyrah Al-Ula, Dar Asy-Syuruq, yang ditulis oleh Mahmud Syaltut pada tahun 1982. Meskipun hanya sampai surah AtTaubah, dalam tafsir tersebut, Mahmud Syaltut banyak berhenti pada satu tema dan menyebutkan beberapa ayat untuk memaparkan tema tersebut secara komprehensif berdasarkan makna-makna ayat yang menyampaikan tema yang sedang dibahas.

\section{b. Frasa Sabilillah dalam Penafsiran Mahmud Syaltut}

Dalam penelitian sebelumnya belum ditemukan pandangan secara khusus tentang sabillah perspektif Mahmud syaltut dalam hukum hukum islam. Ada beberapa hasil penelitian tentang Mahmud Syaltut tentang pandangan beliau tentang dinamisasi hukum islam yang bisa menyesuiakan konteks zamanya sebagaina artikel Nurul Huda dengan judul Dinamisasi Hukum Islam Versi Mahmud Syaltut yang diterbitkan dalam jurnal Sufuf, Volume 19 No 1 tahun 2007. Selain itu juga ada beberapa tentang pandangan politik Mahmud syaltut, karena beliau juga seorang tokoh politik dimasanya.

Khusus terkait masalalah Sabilillah ini dan merujuk pada Tafsir Al-Qur'an Al-Karim (2004: 499), Syaltut menyatakan, "Frasa sabilillah banyak dijumpai dalam Al-Qur'an. Kata sabil berarti jalan peribadahan. Dijumpai pula, kata sabil digabungkan dengan syarr yang berarti kejahatan. Dalam contoh ungkapan disebutkan sabilul mujrimin yang berarti jalan orang-orang yang jahat atau berbuat jahat. Sebaliknya, sabil juga disandingkan dengan lafaz jalalah (Allah) dan mu ‘minin, menjadi sabilullah dan sabilul mu 'minin yang dalam hal ini maknanya sama dengan ash-shirath al-mustaqim (jalan yang lurus). Ketiganya, sama-sama berarti jalan keimanan, kebenaran dan dakwah yang telah digariskan Allah Swt. Amal kebajikan adalah sabilillah, meluhurkan agama Allah juga sabilillah, mengusir musuh dan penjajah juga sabilillah, menegakkan keadilan juga sabilillah, menyampaikan amanah kepada ahlinya juga sabilillah..." Syaltut menyimpulkan, sabilillah bukan lain adalah upayaupaya menegakkan kebenaran, keadilan dan kebaikan.

Hal tersebut terlihat dalam banyak penafsirannya. Misalnya, firman Allah Swt., "Dan perangilah di jalan Allah orang-orang yang memerangi kamu, (tetapi) janganlah kamu melampaui batas, karena sesungguhnya Allah tidak menyukai orang-orang yang melampaui batas. Dan bunuhlah mereka di mana saja kamu jumpai mereka, dan usirlah mereka dari tempat mereka telah mengusir kamu (Mekah); dan fitnah itu lebih besar bahayanya dari pembunuhan, dan janganlah kamu memerangi mereka di Masjidil haram, kecuali jika mereka memerangi kamu di tempat itu. jika mereka memerangi kamu (di tempat itu), Maka bunuhlah mereka. Demikanlah Balasan bagi orang-orang kafir. Kemudian jika mereka berhenti (dari memusuhi kamu), Maka Sesungguhnya Allah Maha Pengampun lagi Maha Penyayang. Dan perangilah mereka itu, sehingga tidak ada fitnah lagi dan (sehingga) ketaatan itu hanya semata-mata untuk Allah. jika mereka berhenti (dari memusuhi kamu), Maka tidak ada permusuhan (lagi), kecuali terhadap orang-orang yang zalim. Bulan haram dengan bulan haram, dan pada sesuatu yang patut dihormati, berlaku hukum kisas. Oleh sebab itu, barangsiapa yang menyerang kaтu, maka seranglah ia, seimbang dengan serangannya terhadapmu. 
bertakwalah kepada Allah dan ketahuilah, bahwa Allah beserta orang-orang yang bertakwa (QS. AlBaqarah [2]: 190-194).

Syekh Syaltut, dalam Al-Qital wa Al-Qur'an (1951:30-31), menyatakan, ayat-ayat tersebut, berikut prinsip-prinsip yang terkandung di dalamnya, menjelaskan sebab-sebab peperangan berikut tujuan-tujuan yang diraih dari peperangan itu. Di dalamnya sedikit pun tak ada ide memaksakan agar orang lain menerima dakwah Islam. Bahkan sebaliknya, ayat-ayat tersebut dan juga ayat-ayat lainnya justru menjelaskan sebab-sebab dilegalkannya peperangan, yaitu kaum Muslimin dimusuhi, diusir, diperkosa hak dan kehormatannya. Adapun tujuan peperangan itu sendiri adalah agar tidak terjadi fitnah dan terlindunginya kebebasan beragama tanpa adanya tekanan dan paksaan. Maka, jika tujuan itu sudah tercapai, peperangan juga harus dihentikan. Prinsip-prinsip itu banyak disampaikan dalam ayat perang dalam surah An-Nisa', Al-Anfal dan At-Taubah. Dari sini tampak jelas bahwa sabilillah, yang dalam ayat tersebut dinyatakan sebagai perang di jalan Allah Swt., tetapi dibatasi oleh sebab dan tujuan seperti yang telah digariskan Allah Swt. dalam firman-Nya itu. Jadi, sekali-kali perang bukanlah untuk memaksakan satu ide atas nama Allah.

Lalu, dengan cara apa orang-orang diseru untuk memeluk Islam? Syaltut (1951: 16-18) menjawab, dalam Al-Qur'an, Nabi Saw. mendapatkan pengajaran dari para nabi dan rasul sebelumnya. Bahkan secara tegas, Nabi Saw. diperintahkan agar meneladani mereka, "Mereka itulah orang-orang yang telah diberi petunjuk oleh Allah, maka ikutilah petunjuk mereka” (QS. Al-An'am [6]: 90), demikian perintah Allah Swt. kepada Nabi-Nya. Dakwah mereka sama, yaitu tauhid dan amal saleh. Lalu, secara khusus Nabi Saw. diperintahkan menggunakan cara dan sarana dakwahnya. Allah Swt. berfirman, "Serulah (manusia) kepada jalan Tuhan-mu dengan hikmah dan pelajaran yang baik dan bantahlah mereka dengan cara yang baik. Sesungguhnya Tuhanmu Dialah yang lebih mengetahui tentang siapa yang tersesat dari jalan-Nya dan Dialah yang lebih mengetahui orang-orang yang mendapat petunjuk" (QS. An-Nahl [16]: 125). Syaltut menyatakan, Islam itu mudah, dakwahnya pun juga mudah, maka yang mudah ini tak perlu dipaksakan. Maka, yang berbelit-belit, susah dan memaksakan bukanlah dakwah Islam. Jadi, menyeru kepada jalan Tuhan alias dakwah bukan dengan cara memaksa.

Namun demikian, pemaknaan sabilillah justru lebih luas lagi dalam firman Allah Swt., ia bukan lagi melulu soal perang, tetapi juga menyangkut harta dan kemaslahatan orang banyak. Maka dari itu, Allah Swt. berfirman, "Sesungguhnya zakat-zakat itu, hanyalah untuk orang-orang fakir, orang-orang miskin, pengurus-pengurus zakat, para mualaf yang dibujuk hatinya, untuk (memerdekakan) budak, orang-orang yang berhutang, untuk jalan Allah dan untuk mereka yuang sedang dalam perjalanan" (QS. At-Taubah [9]: 60). Menurut Syaltut (Al-Fatawa 2004: 128), "fi sabilillah" (untuk jalan Allah) bukan hanya dialokasikan untuk para kombatan, militer atau peperangan, tetapi makna sabilillah mencakup seluruh kemaslahatan umum bagi kaum Muslimin. Kata tersebut mencakup masjid, rumah sakit, industri militer, infra struktur dan hal-hal lain yang manfaatnya dirasakan oleh kaum Muslimin.

Konsep sabilillah juga menyangkut hubungan antar sesama Muslim. Allah Swt. berfirman, "Sesungguhnya orang-orang yang beriman dan berhijrah serta berjihad dengan harta dan jiwanya pada jalan Allah dan orang-orang yang memberikan tempat kediaman dan pertolongan (kepada orang-orang muhajirin), mereka itu satu sama lain lindung-melindungi. Dan (terhadap) orang-orang yang beriman, tetapi belum berhijrah, Maka tidak ada kewajiban sedikitpun atasmu melindungi mereka, sebelum mereka berhijrah. (akan tetapi) jika mereka meminta pertolongan kepadamu dalam (urusan pembelaan) agama, Maka kamu wajib memberikan pertolongan kecuali terhadap kaum yang telah ada Perjanjian antara kamu dengan mereka. dan Allah Maha melihat apa yang kamu kerjakan. Adapun orang-orang yang kafir, sebagian mereka menjadi pelindung bagi sebagian yang lain. jika kamu (hai Para muslimin) tidak melaksanakan apa yang telah diperintahkan Allah itu, niscaya akan terjadi kekacauan di muka bumi dan kerusakan yang besar. Dan orang-orang yang beriman dan berhijrah serta berjihad pada jalan Allah, dan orang-orang yang memberi tempat kediaman dan 
memberi pertolongan (kepada orang-orang muhajirin), mereka Itulah orang-orang yang benar-benar beriman. mereka memperoleh ampunan dan rezki (nikmat) yang mulia” (QS. Al-Anfal [8]: 72-74).

Menurut Syaltut (Tafsir Al-Qur'an 2004: 403), konteks ayat tersebut adalah hubungan antara kaum Anshar dan Muhajirin. Kedua kelompok ini dinyatakan sebagai orang-orang yang berada di jalan Allah apabila mereka saling membantu dan menolong, bahkan mereka yang belum hijrah, tetapi sudah beriman, harus mereka bela dengan cara menolongnya. Tegasnya, orang Mukmin pelindungnya adalah sesama Mukmin, dan kaum musyrik pelindungnya juga orang musyrik, tak ada perlindungan antara kaum Mukmin dengan kaum musyrik.

\section{c. Implementasi Pemaknaan Sabilillah dalam Hukum Islam}

Para ulama klasik sepakat bahwa yang dimaksud sabilillah adalah orang-orang yang terlibat peperangan dalam rangka membela agama Allah (Tafsir Ibnu Katsir, Jilid II: 367). Mahmud Syaltut menegaskan bahwa dengan membaca pendapat dalam literatur kitab-kitab fiqh terhadap permasalahan tersebut tidaklah memuaskan. Dalam pandangannya, sabilillah dalam ayat yang terangkai dengan mustahiq zakat adalah berkaitan dengan maslahah al-ammah (kemaslahatan umum) yang tidak bisa ditafsiri hak milik individu. Yang dimaksud dengan kemaslahatan umum di sini adalah pembentukan pasukan perang yang kuat untuk persiapan pertahanan negara dan membela kehormatan bangsa meliputi bidang personil, akomodasi, dan peralatan. Di samping itu pengembangan infra struktur dalam suatu negara guna meningkatkan kesejahteraan bagi warganya meliputi pembangunan rumah sakit, jembatan, sekolahan, sarana transportasi, serta segala perlengkapan yang berhubungan dengan syiar Islam yang perlu disosialisasikan secara massal termasuk kebutuhan juru dakwah yang handal juga merupakan bagian dari upaya kemaslahatan umum (Mahmud Syaltut, 1996: 111).

Pendapat Syaltut tentang sabilillah di atas didasarkan pada perluasan makna sabilillah yang secara esensial meliputi segala sesuatu yang dapat memelihara kehormatan bangsa baik dalam hal materiil maupun spirituil sekaligus menampilkan jatidiri bangsa sebagai identitas pembeda dengan bangsa yang lainnya. Apabila dilihat dari sudut pandang prinsip-prinsip ijtihad tampaknya Syaltut menggunakan pendekatan maslahah ketika menafsirkan makna sabilillah. Berdasarkan berprinsip maslahah esensi suatu hukum tampak lebih hidup dan memberi jawaban nyata terhadap realitas masyarakat.

Dari beberapa pemikiran Mahmud Syaltut di atas menunjukkan, bahwa apa yang diungkapkan Syaltut tidak lain merupakan salah satu bentuk upaya mengembangkan pemahaman terhadap permasalahan hukum terkait dengan perubahan sosial sehingga hukum Islam tampak dinamis dalam menyikapi permasalahan kontemporer yang disebabkan perkembangan zaman. Hakekat dinamisasi ditunjukkan Syaltut dengan merumuskan kembali ketentuan hukum dengan mengedepankan relasi teks dengan konteks. Terlebih tujuan utama disyariatkan hukum adalah untuk kemaslahatan umat manusia. Kemaslahatan tersebut bersifat dinamis dan fleksibel. Maksudnya, pertimbangan kemaslahatan tersebut seiring dengan perkembangan zaman. Sebagai konsekuensinya, bisa jadi yang dianggap maslahat pada masa lalu belum tentu dianggap maslahat pada masa sekarang (Amir Muallim dan Yusdani, 1999: 38).

Ketika memahami kasus hukum, Syaltut tidak hanya terpaku pada normativitas suatu teks. Pendekatan historis ia gunakan dalam memahami kasus hukum. Di samping itu Syaltut juga menggunakan pendekatan sosiologis ketika membahas tentang permasalahan memerdekakan budak (ar-Riqab) dan makna sabilillah. Dalam hal ini Syaltut mengkaitkan bunyi teks dengan konteks sosial pada masa itu. Dengan keluasan pandangan dan pemikirannya tentang hukum Islam tidak lantas menghiraukan teks. Dengan pemahaman demikian, hukum Islam ditangan Syaltut tampil dinamis sesuai dengan konteks zamannya. 
Beranjak dari penafsiran frasa sabilillah yang mencakup seluruh aspek kehidupan, Syaltut bukan hanya menyampaikannya dalam buah pikiran atau ide, tetapi lebih jauh beliau membumikan penafsiran itu dalam fatwanya. Berikut ini beberapa fatwa Syekh Syaltut yang berkaitan dengan penafsirannya terhadap sabilillah:

Pertama, zakat yang diberikan untuk pembangunan masjid. Syekh Syaltut (Al-Fatawa: 128-129) memfatwakan, jika masjid yang dibangun adalah masjid satu-satunya, atau ada masjid lain tetapi masjid itu sudah tak memadai menampung jamaah maka sah berzakat untuk masjid itu atas nama sabilillah. Atau juga, dibangunnya satu masjid yang lain karena masjid yang pertama sudah tidak menampung juga sah mengalokasikan zakat untuk masjid itu atas nama "sabilillah" yang terdapat dalam ayat, "Sesungguhnya zakat-zakat itu, hanyalah untuk orang-orang fakir, orang-orang miskin, pengurus-pengurus zakat, para mualaf yang dibujuk hatinya, untuk (memerdekakan) budak, orangorang yang berhutang, untuk jalan Allah dan untuk mereka yuang sedang dalam perjalanan" (QS. AtTaubah [9]: 60).

Kedua, pembiayaan perang. Dalam menyampaikan fatwanya seperti yang telah disebutkan, Syekh Syaltut (Tafsir Al-Qur'an: 449) menegaskan, bahwa frasa sabilillah tidak hanya terbatas pada perang atau para pasukan. Syekh Syaltut menyandarkan pendapatnya pada riwayat Al-Qaffal dari beberapa fukaha. Ini artinya, makna frasa sabilillah tidak hilang dari pertama kali makna tersebut digunakan. Dengan kata lain, syarat, rukun, adab berperang, berikut kelengkapannya juga masuk dalam kerangka sabilillah. Dan, berdasarkan ini pula. Syaltut membolehkan jika pemerintah mengalokasikan pendapatan negara dari sektor zakat untuk pembelian alusista atau proyek pertahanan negara.

Ketiga, memerangi kaum sparatis (pemberontak). Dalam Al-Qital wa Al-Qur'an (1951: 24), Syaltut membedakan peperangan dalam dua kategori; perang dengan musuh non-Muslim dan perang saudara sesama Muslim atau antargolongan yang berdomisili di teriotorial wilayah negara Muslim. Dalam peperangan sesama Muslim, Syaltut memetakan lagi dalam konsep perang dalam negeri. Dalam pemetaannya, Syaltut merincikan bahwa konflik dalam negeri dapat terjadi antargolongan yang menempati suatu teritorial negara Muslim dan antara rakyat melawan negara atau pemerintah. Dalam dua konflik dalam negeri itulah negara dituntut untuk menyelesaikan konflik itu, bahkan jika terpaksa, dan setelah menempuh berbagai upaya damai, boleh menggunakan senjata, baik sebagai pihak yang bersengketa ataupun sebagai penengah (mediator).

Betul bahwa konflik dalam negeri frasa sabilillah tak muncul sebagai konteks peperangan. Akan tetapi, mengingat bahwa satu di antara tujuan perang adalah memadamkan fitnah, maka perang yang dilakukan oleh negara atau pemerintah meskipun sebagai pihak yang terlibat konflik, tetap dinyatakan sebagai jihad fi sabilillah. Meskipun demikian, Syaltut (Al-Qur'an wa Al-Qital: 24-25) mengingatkan, dalam menangani kaum sparatis ini harus tetap adil. Beliau mengutip firman Allah Swt., "Dan kalau ada dua golongan dari mereka yang beriman itu berperang hendaklah kamu damaikan antara keduanya! Tapi kalau yang satu melanggar perjanjian terhadap yang lain, hendaklah yang melanggar perjanjian itu kamu perangi sampai surut kembali pada perintah Allah. Kalau Dia telah surut, damaikanlah antara keduanya menurut keadilan, dan hendaklah kamu Berlaku adil; Sesungguhnya Allah mencintai orang-orang yang berlaku adil” (QS. Al-Hujurat [49]: 10).

Keempat, pembiayaan pembangunan infra struktur dan parasarana umum oleh negara dari alokasi zakat. Dalam pandangan Syekh Syaltut, alokasi pemdistribusian zakat terbagi dalam 2 kelompok besar; ada yang bersifat pribadi khusus dan ada yang bersifat kemaslahatan umum. Pada kelompok kemaslahatan umum ini, Syaltut menyatakan bahwa sabilillah inilah yang menjadi pintu bagi negara atau pemerintah untuk menghimpun dana pembangunan infrastruktur dan prasarana umum, seperti rumah sakit, sekolahan, jalan dst. Tegasnya, sabilillah dalam konsep Syaltut ( $A l$ Fatawa: 118-119) adalah segala hal yang urgen bagi tegaknya pemerintah kaum Muslimin. 
Kelima, cara berdakwah. Syaltut (Al-Fatawa: 128) memandang, tak ada pemaksaan dalam agama. Dengan kata lain, sarana dakwah yang dibenarkan hanyalah hikmah dan tutur kata yang baik. Kaitan dakwah dengan jalan Tuhan, atau yang dalam Al-Qur'an disebutkan sebagai sabili rabbika, adalah dakwah di jalan Allah bukanlah dengan paksaan. Maka, jika terjadi pemaksaan, hal tersebut bukan lagi di jalan Allah.

Keenam, terkait firman Allah Swt., "Mengapa kamu tidak mau berperang di jalan Allah dan (membela) orang-orang yang lemah baik laki-laki, wanita-wanita maupun anak-anak yang semuanya berdoa: "Ya Tuhan Kami, keluarkanlah Kami dari negeri ini (Mekah) yang zalim penduduknya dan berilah Kami pelindung dari sisi Engkau, dan berilah Kami penolong dari sisi Engkau!" (QS. AnNisa` [4]: 75), Syaltut (Al-Qur'an wa Al-Qital: 42) berani keluar dari makna leksikal ayat. Menurutnya, berperang di jalan Allah adalah menyelamatkan kaum lemah dan berbuat baik kepada sesama manusia, atau dengan kata lain berperang demi menghalau segala faktor buruk dan merusak. Artinya, perang yang dimaksudkan Syaltut bukan melulu soal angkat senjata, dan membunuh atau terbunuh. Akan tetapi, yang lebih penting dari itu adalah mengangkat derajat kaum lemah dan mencegah kerusakan. Tegasnya, memerangi kemiskinan, memberantas kebodohan, meningkatkan kesehatan dan mendatangkan kemaslahatan adalah medan jihad yang seharusnya mendapatkan perhatian lebih, khsuusnya di masa damai seperti sekarang ini. Pasalnya, untuk masa sekarang ini, makna inilah yang paling relevan dalam rangka implementasi makna sabilillah.

\section{Kesimpulan}

Berdasarkan paparan yang telah disampaikan, disimpulkan sebagai berikut: Pertama, sabil berarti (jalan). Akan tetapi, dalam banyak penggunaan, khususnya dalam Al-Qur'an, terlebih lagi jika kata sabil di-mudhaf-kan dengan lafaz jalalah (Allah), alias agama Allah, maka makna tersebut harus diartikan sesuai konteks kalimatnya. Berdasarkan penafsiran Syaltut, impementasi sabilillah tidak melulu harus angkat senjata alias perang. Bahkan, seandainya harus berperang ada beberapa syarat dan rukun yang harus dipenuhi. Ketiga, setelah memaparkan beberapa ayat yang berkaitan dengan frasa sabilillah, dalam pandangan Syaltut dapat disimpulkan frasa ini mencakup nilai-nilai universal kehidupan yang ditetapkan oleh Islam; kebaikan, keadilan, kerja sama dan kasih sayang. Dalam tataran konkret, frasa sabilillah meski dinyatakan dalam konteks wacana peperangan, tetapi nilai-nilai keadilan tetap harus ditegakkan. Demikian pula, dalam konteks dakwah nilai-nilai kasih sayang tetap harus ditegakkan. Bahkan, dalam zakat pun ada unsur kerja sama untuk merealisasikan kemaslahatan umum. Keempat, sebagai pakar fikih, Mahmud Syaltut menurunkan gagasannya itu dalam fatwanya. Baginya, sabilillah bukan hanya soal perang dan tetek-bengeknya, tetapi bagiamana merealisasikan tujuan syariat itu sendiri. Karena itu, beliau membolehkan zakat diberikan ke masjid ketika kemaslahatan masjid itu merealisasikan tujuan syariat Islam. Wallahu a'lam. [*]

\section{Daftar Pustaka}

Al-Farmawi, Abdul Hayyi, (1977). Al-Bidayah fi At-Tafsir Al-Maudhu'i Dirasah Manhajiyyah Maudhu'iyyah, Kairo: Maktabah Jumhuriyah.

Al-Qairawani, Ahmad bin Faris, (1979). Mu'jam Maqayis Al-Lughah, Beirut: Dar Al-Fikr

Al-Qusyairi, Muhammad bin Ali, (2003). Syarh Al-Arba'in An-Nawawiyyah, Riyad: Mu’assasah ArRayyan.

Arief, Abdul Salam, (2003). Pembaruan Pemikiran Hukum Islam Antara Fakta dan Realita, Yogyakarta: Lesfi. 
Baidan, Nashiruddin dan Aziz, Erwati, (2000). Metodologi Khusus Penelitian Tafsir, Yogyakarta: Pustaka Pelajar.

Chaer, Abdul, (2012). Linguistik Umum, Jakarta: Reneka Rineka Cipta.

Fauzi, Asyraf, (1997). Syuyukh Al-Azhar, Kairo: Syirkah Al-Arabiyah.

http://www.almasryalyoum.com/news/details/1146250

http://www.dar-alifta.org/AR/ViewScientiest.aspx?!ID=66

http://www.youtu.be/4klWc0iPAxw.

Imarah, Muhammad, (tt). Asy-Syaikh Syaltut; Imam fi Al-Ijtihad wa At-Tajdid, Kairo: Dar As-Salam.

Izzan, Ahmad, (2014). Metodologi Ilmu Tafsir, Bandung: Tafakur

Jum'ah, Ali, (2017). Sejarah Ushul Fikih, Depok: Keira Publishing.

Katsir, Ibnu Katsir, (1980). Tafsir Ibn Katsir, Jilid II, Beriut: Darul Fikr.Muallim, Amir dan Yusdani, (1999). Konfigurasi Pemikiran Hukum Islam, Yogyakarta: UII Press.

Mun'im, Muhammad Abdul, (1996). Al-Azhar fi Alfi ‘Am, Kairo: Maktabah Al-Azhariyah li Turats.

Munawwar, Said Agil Husin, (2002). Al-Qur'an Membangun Tradisi Kesalehan Hakiki, Jakarta : Ciputat Press.

Syaltut, Mahmud, (1951). Al-Qur'an wa Al-Qital, Kairo, Dar Al-Kitab Al-`Arabi.

Syaltut, Mahmud, (1966). Al-Islam Aqidah wa Syariah, Darul Qalam.

Syaltut, Mahmud, (2004). Al-Fatawa, Dirasah li Musykilah Al-Muslim Al-Mu'ashir fi Al-Hayah AlYaumiyyah Al-'Ammah, Kairo: Dar El-Shorouq.

Syaltut, Mahmud, (2004). Tafsir Al-Qur'an Al-Karim Al-Ajza`Al-'Asyrah Al-Ula, Kairo, Dar ElShouruq.

Zulfikar, Ahmad. Romdloni, Muhammad Afwan, (2019). Al-qur`an dan Relasi Umat Beragama; Prinsip Dasar Harmoni Antar Umat Beragama Perspektif Al-qur'an. Journal Islamic of Civilization, Vol 1. No. 1. April 2019. DOI : 10.33086/jic.v1i01 